\title{
Pelatihan Pembuatan Kerupuk Ikan Tuna untuk Meningkatkan Pendapatan Masyarakat di Desa Gampong Jalan Kecamatan Idi Rayeuk Kabupaten Aceh Timur
}

\author{
Falaq Amraini*1, Alfikas Zarkasih ${ }^{2}$, Nova Purnama Lisa ${ }^{3}$, Nina Fahriana ${ }^{4}$ \\ 1,2,3,4Teknik Sipil, Fakultas Teknik, Universitas Samudra, Indonesia \\ *e-mail: falaqambraini@gmail.com ${ }^{1}$, alfikaszarkasih58@gmail.com ${ }^{2}$
}

\begin{abstract}
Abstrak
Pengabdian Masyarakat ini bertujuan untuk meningkatkan pengetahuan dan skill kelompok ibu-ibu di desa gampong jalan melalui transformasi teknologi pengolahan, pengemasaran, pemasaran dan manajemen usaha dengan bahan dasar ikan tuna menjadi produk olahan kerupuk ikan tulang ikan tuna. Permasalahan rendahnya pengetahuan dan keterampilan (IRT) desa gampong jalan dalam mengolah hasil laut yaitu ikan, sehingga menjadi produk yang bernilai ekonomis. Target dari program ini adalah terbentuknya unit usaha yang mengembangkan produk makanan dari bahan dasar ikan tuna. Secara khusus program ini bertujuan untuk melatih Ibu-ibu Rumah Tangga (IRT) desa gampong jalan untuk memproduksi kerupuk ikan tuna. Pelatihan ini di berikan mulai dari cara pengolahaan, pengemasan, pemasaran sampai Metode yang akan di terapkan untuk mencapai tujuan atau target adalah metode demontrasi, pelatihan/penyuluhan. Kegiatan ini melibatkan para anggota mahasiswa Kuliah Kerja Nyata yang di dampingi oleh dosen pendamping program studi Teknik mipa dengan peserta para ibu-ibu rumah tangga (IRT) kelurahan gampong jalan dan masyarakat di kecamatan Idi Rayeuk kabupaten aceh timur. Hasil yang di capai pada kegiatan ini adalah Kelompok ibu rumah tangga (IRT) desa gampong jalan telah memahami dan memiliki keterampilan dalam wirausaha, dan Mengetahui cara pengelolaan usaha yang lebih terstruktur, adanya produk kerupuk tulang ikan tuna berbagai rasa pedas dan manis serta memahami bagaiman cara memasarkan produk dengan adanya inovasi kemasan dan penggunaan teknologi. Hasil evaluasi yang telah dilakukan dapat di ketahui bahwa pengetahuan peserta terkait pengolahan tulang ikan tuna meningkat dan membuka pikiran peserta untuk memanfaatkan peluang yang ada untuk meningkatkan pendapatan. Sekitar 85 persen peserta secara aktif menanggapi positif keterampilan dan pengetahuan yang di sampaikan oleh Pengabdi.
\end{abstract}

Kata kunci: Ikan Tuna, Iptek bagi Masyarakat, Kerupuk, Pemberdayaan

\begin{abstract}
This Community Service aims to improve the knowledge and skills of the women's group in the village of Gampong Jalan through the transformation of processing technology, marketing, marketing and business management with tuna fish as basic ingredients into processed tuna fish bone crackers. The problem is the lack of knowledge and skills (IRT) in the village of Gampong Jalan in processing marine products, namely fish, so that they become economically viable products. The target of this program is the formation of a business unit that develops food products from tuna fish. This special program aims to train housewives (IRT) in the village of Gampong Jalan to produce tuna fish crackers. This training is provided starting from the way of processing, packaging, marketing. The method that will be applied to achieve the goal or target is the method of demonstration, training / counseling. This activity involved members of the Real Work Lecture students who were accompanied by assistant lecturers for the Mathematics and Natural Sciences study program with participants from housewives (IRT) in the village of Gampong Jalan and the community in Idi Rayeuk sub-district, East Aceh district. The results achieved in this activity are that the housewife group (IRT) in the village of Gampong Jalan has understood and has skills in entrepreneurship, and knows how to manage a more structured business, there are tuna fish bone crackers products with various spicy and sweet flavors and understand various ways of marketing. products with packaging innovation and the use of technology. The results of the evaluation that have been carried out can be seen that the knowledge of participants regarding tuna bone processing has increased and opened the minds of participants to take advantage of existing opportunities to increase income. 85 percent of participants actively enjoy the positive skills and knowledge imparted by Servants.
\end{abstract}

Keywords: Crackers, Empowerment, Tuna Fish Bones, Science and Technology for The Community 


\section{PENDAHULUAN}

Pembangunan desa Gampong jalan diawali oleh keinginan sekelompok orang untuk membuat suatu pemukiman pada ratusan tahun yang lalu. Pada awalnya desa Gampong Jalan merupakan daerah yang sangat dipenuhi oleh perkebunan, seiring berjalannya waktu desa gampong jalan berkembang dari daerah perdesaan yang perkebunan yang banyak menjadi daerah perdesaan yang mempunyai potensi menjadi daerah perdagangan dan Kawasan pendidikan. Jalan menuju desa Gampong Jalan merupakan jalan lintas Samudra medan-banda aceh dengan jarak tempuh kira-kira 5 Menit ke Kantor Kecamatan. Desa Gampong jalan berada di pemukiman Idi rayeuk

Desa ini kemudian berubah menjadi sebuah permukiman yang besar ketika sekelompok orang berdatangan ke Kecamatan Idi Rayeuk baik itu penduduk yang ada di kabupaten Aceh Timur maupun yang berasal dari luar kabupaten Aceh Timur. Seiring dengan bertambahnya jumlah penduduk semakin membuat masyarakat terus mengembangkan diri untuk melanjutkan kehidupan, sebagian besar penduduknya saat itu adalah Pegawai Negeri Sipil (PNS), Pedagang., Nelayan, Buruh, dan Perternak.

Desa Gampong Jalan merupakan salah satu desa yang terletak di kabupaten Aceh Timur dengan pimpinan keucjik saat ini yang Bernama Munawar. jika ditinjau secara geografis, luas wilayah keseluruhan desa Gampong Jalan adalah $\pm 162 \mathrm{Ha} / \mathrm{M}^{2}$. Batas wilayah sebelah utara desa Gampong Jalan berbatasan dengan kampung Tanjong Kapai dan Alue dua muka S, sebelah selatan berbatasan dengan kampung Gampong Buket Pala dan Buket Juara, sebelah timur berbatasan dengan kampung baro dan Sungai, dan sebelah barat berbatasan dengan Gampong Teupin Batee. Desa Gampong Jalan memiliki 4 dusun diantaranya dusun T. Banta, dusun Dulhok, dusun Petua Amin, dan Dusun T. Thaeb.

Luas wilayah desa Gampong Jalan mencapai $\pm 162 \mathrm{Ha} / \mathrm{M}^{2}$, dihuni oleh penduduk sebanyak (712 KK). Luas Persawahan $20 \mathrm{Ha} / \mathrm{M}^{2}$, luas ladang $10 \mathrm{Ha} / \mathrm{M}^{2}$, luas tempat pemakaman umum $24 \mathrm{Ha} / \mathrm{M}^{2}$, dan luas perkebunan $5 \mathrm{Ha} / \mathrm{M}^{2}$. Menurut data statistik kantor Keuchik desa Gampong Jalan, bahwa jumlah penduduk desa Gampong Jalan secara keseluruhan sebanyak 2770 jiwa. Dengan jumlah pria sebanyak 1285 jiwa dan wanita sebanyak 1485 jiwa.

Pengabdian Masyarakat ini bertujuan untuk meningkatkan pengetahuan dan skill kelompok ibu-ibu di desa gampong jalan melalui transformasi teknologi pengolahan, pengemasaran, pemasaran dan manajemen usaha dengan bahan dasar ikan tuna menjadi produk olahan kerupuk ikan tulang ikan tuna. Permasalahan rendahnya pengetahuan dan keterampilan (IRT) desa gampong jalan dalam mengolah hasil laut yaitu ikan, sehingga menjadi produk yang bernilai ekonomis.

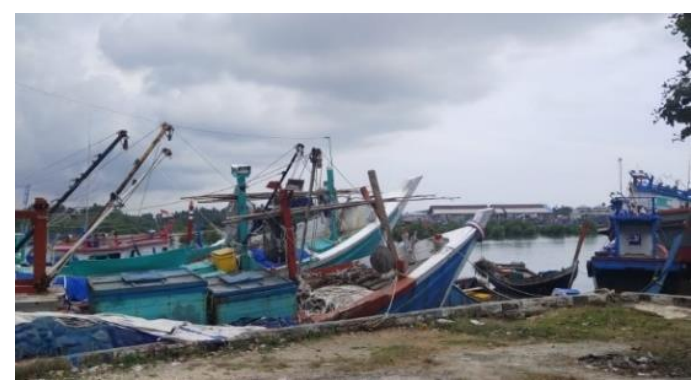

Gambar 1. Survey potensi lokasi

Secara umum mata pencaharian warga masyarakat gampong jalan yaitu sebagai PNS, Perikanan, peternak, pedagang dan lain-lain. Mayoritas pekerjaan warga adalah PNS, karena memang banyak Sekolah Pendidikan yang ada di sekitar kawasan Desa Gampong jalan ini. Permasalahan yang umum terjadi di Desa gampong jalan ini adalah kurang maksimalnya pengelolaan sumber daya hasil laut desa, sehingga perlu adanya usaha untuk mengoptimalkan sumber daya laut tersebut.

Pengolahan ikan Tuna merupakan salah satu cara untuk menyelamatkan hasil panen yang disertai dengan usaha peningkatan nilai tambah melalui rasa, aroma, kenampakan produk 
serta kandungan gizinya. Adanya usaha diversifikasi produk hasil laut diharapkan dapat meningkatkan pendayagunaan dan usaha pengolahan hasil laut, khususnya perikanan laut untuk diolah menjadi produk baru yang bergizi tinggi, enak, murah, dan mudah didapat (Pratiwi et al., 2016). Senada dengan penjelasan diatas maka hadirnya Progam Kuliah Kerja Nyata Tematik (KKN-T) yang dilaksanakan oleh Universitas Samudra pada Tahun 2021 guna untuk membantu, mendukung serta mengoptimalkan pendapatan ekonomi masyarakat yang ada di Desa gampong jalan Aceh timur terkhususnya pada sektor perikanan. salah satu program kerja yang diberikan untuk membantu pemasukan pendapatan masyarakat setempat yaitu olahan daging segar ikan tuna menjadi produk pangan makanan kerupuruk ikan varian rasa. kerupuk merupakan produk olahan makanan yang digemari oleh masyarakat dikalangan semua usia.

Kerupuk ikan merupakan salah satu produk olahan daging dengan menggunakan teknologi restrukturisasi, yaitu teknologi dengan memanfaatkan potongan daging yang relatif kecil dan tidak beraturan, kemudian dilekatkan kembali menjadi ukuran yang lebih besar (Agusta et al., 2020). kerupuk yang pada umumnya menggunakan udang, dapat digantikan dengan menggunakan ikan. Pada dasarnya kerupuk ikan mirip dengan kerupuk udang. Kerupuk ikan merupakan makan kering yang dibuat dari tepung atau nasi dengan penambahan daging ikan dan bahan lain yang diizinkan (The National Standardization Body of Indonesia, 2009). Masyarakat Indonesia mengonsumsi kerupuk sebagai camilan atau sebagai menu pelengkap makan utama, misalnya sebagai lauk. (Kusuma et al., 2013)menyatakan bahwa tepung tapioka merupakan bahan baku utama yang digunakan sebagai bahan pembuatan kerupuk. Meskipun demikian, masyarakat Indonesia sudah terbiasa menggunakan bahan lain seperti nasi atau sagu. Selain itu, penambahan bahan lain sebagai umum dilakukan untuk meningkatkan nilai gizi dari kerupuk. Salah satunya adalah penambahan daging ikan yang berfungsi sebagai penambah cita rasa dan aroma. Selain itu, penambahan daging ikan berfungsi menambah kandungan protein pada kerupuk. Persentase daging ikan yang ditambahkan tidak lebih dari 30\% (Purnamayati et al., 2019) Beberapa jenis ikan yang umum digunakan ialah ikan nilai, ikan tengiri, ikan tuna (Deni et al., 2007) atau jenis ikan lain seperti ikan tongkol. Ikan tongkol adalah salah satu ikan laut yang memiliki daging tebal dengan kandungan protein tinggi. Selain mengandung protein, ikan tongkol juga mengandung omega 3, vitamin dan mineral yang dibutuhkan oleh tubuh manusia (Hafiludin, 2011). Selain itu, ikan tongkol memiliki rasa yang lezat. Inovasi lain yang diberikan pada pelatihan pembuatan kerupuk ikan tongkol saat ini ialah penggunaan daun pisang untuk membungkus adonan kerupuk sehingga tercipta aroma yang khas dari kerupuk ikan tersebut. Dengan demikian pelatihan "Pengolahan Kerupuk Ikan yang diberikan kepada Mitra yang ada di Desa Ekas Buana" diharapkan mampu diterapkan dan dijadikan sebagai usaha dalam upaya meningkatkan ekonomi masyarakat.

Ikan tuna merupakan hasil perikanan yang mempunyai nilai ekonomis penting baik sebagai komoditi ekspor maupun sebagai konsumsi lokal. Menurut data tahun 2004 dan 2005 menunjukkan bahwa ikan tuna termasuk jenis ikan dominan sekitar 301 ton lebih(Setyowati et al., 2018). Ikan Tuna memiliki kandungan gizi sangat yang baik bagi pertumbuhan tubuh. kadar rendah lemak dan kalori yang kaya akan protein dan omega-3 membuat ikan tuna menjadi sangat diminati(Pade et al., 2021). Terlebih lagi ikan tuna merupakan salah satu produk ikan yang paling aman dijangkau. Selain itu juga dapat dijual segar, ikan tuna juga dapat dibekukan dan sudah merambah ke produk olahan-olahan tuna lainnya. Ikan Tuna telah banyak diolah menjadi berbagai produk pangan antara lain tahu tuna, nugget, siomay, sosis, dan berbagai produk pangan lainnya. Selain menarik minat konsumen untuk mengkonsumsi ikan tuna, berkembangnya usaha olahan ikan tuna mampu mengurangi pengangguran dan sekaligus meningkatkan pendapatan bagi masyarakat yang bekerja pada usaha ini.

\section{METODE}

Dalam mengatasi masalah yang terjadi pada mitra sebagaimana yang telah diuraikan, maka dalam program pengabdian kepada masyarakat ini di tawarkan beberapa metode 
pendekatan yang dapat membantu menyelesaikan masalah yaitu dengan metode demontrasi, pelatihan/penyuluhan (Huda et al., 2021).

Kegiatan pelaksanaan program pengabdian pada masyrakat terbagi menjadi tiga tahap, yaitu tahap persiapan, pelaksanaan dan tahap monitoring. Berikut rincian tahapan yang di laksanakan:

a. Tahap persiapan, dilakukan sebelum kegiatan IPTEK yang akan disampaikan kepada kelompok mitra yang meliputi penyusunan program kerja, penyusunan modul pelatihan, persiapan sarana dan prasarana pelatihan. Persiapan ini meliputi persiapan kemasan, ikan tuna berserta bumbu- bumbu yang digunakan, koordinasi lapangan dan sosialisasi.

b. Tahap Pelaksanaan, terdiri dari beberapa kegiatan yaitu: sosialisasi program, pelatihan pembuatan ikan tuna, memberikan pemahaman inovasi kemasan, penggunaan teknologi untuk pemasaran dan manajemen usaha.

c. Tahap Evaluasi, terdiri atas tahap monitoring dan evaluasi, Monitoring dilakukan secara intensif oleh tim pelaksana setiap kegiatan berlangsung untuk memastikan agar pelaksanaan kegiatan dapat berjalan sesuai rencana yang telah ditentukan. Evaluasi dilakukan sejalan dengan monitoring, sehingga jika ada kendala akan segera di selesaikan. Evaluasi dilakukan setiap tahap kegiatan, adapun rancangan evaluasi memuat uraian bagaimana dan kapan evaluasi akan dilakukan, Jadi pernyataan yang dapat disampaikan pada tahap evaluasi ini adalah kriteria, indicator pencapaian tujuan, dan tolak ukur yang digunakan untuk menyatakan keberhasilan dari kegiatan yang di lakukan. Memberikan bimbingan kepada mitra untuk terus melaksanakan pengolahan ikan tuna menjadi kerupuk ikan tuna dengan berbagai rasa untuk meningkatkan pendapatan dan mendukung program pemerintah dalam pembukaan lapangan kerja baru khususnya didesa gampong jalan.

Tabel 1. Bahan dan Alat

\begin{tabular}{cc}
\hline Jenis peralatan & Bahan-bahan \\
\hline Pisau & Tepung Tapioka 1/2 kg \\
Telenan & 5 Siung bawang putih (halus) \\
Wajan & 2 Bungkus penyedap rasa \\
plastik & $1 \frac{1}{2}$ ons Daging ikan tuna \\
Baskom & 1 butir Telur \\
Kompor & 1 sendok soda kue \\
Panci Kukus & 1 sendok ketumbar bubuk \\
plastik & Air panas secukupnya \\
alat penggiling ikan & \\
\hline
\end{tabular}

Adapun proses proses pembuatan kerupuk ikan tuna adalah sebagai berikut.

a. Campur semua bahan, kemudian diaduk secara manual

b. Tumpahkan air panas sedikit demi sedikit hingga kalis.

c. Setelah kalis, bentuk adonan meyerupai lontong dengan menggunakan tangan secara manual, kemudian dibalut menggunakan plastik.

d. Kukus selama kurang lebih 1 jam.

e. Setelah dikukus selama 1 jam, kemudian dipotong tipis-tipis.

f. Setelah dipotong, lalu dijemur hingga kering (3 hari).

g. Setelah kering kerupuk siap digoreng dan disajikan.

\section{HASIL DAN PEMBAHASAN}

\subsection{Hasil Kegiatan}

Sesuai dengan jadwal, metode dan rencana pelaksanaan program yang sudah ditentukan maka hasil yang di peroleh dalam kegiatan ini adalah sebagai berikut: 
a. Peserta yang datang dan mengikuti kegiatan berjumlah sebanyak 30 orang di undang dengan komposisi peserta terdiri dari ibu rumah tangga dan bapak-bapak terdiri dari sekertaris geujik dan aparatur desa gampong jalan, tokoh pemuda, tokoh masyarakat

b. Beberapa keterampilan berhasil di transfer kepada mitra meliputi pelatihan pembuatan kerupuk ikan tuna, inovasi kemasan, pemasaran dan manjemen usaha.

c. Peserta pelatihan yaitu ibu-ibu Rumah tangga istri nelayan dan bapak-bapak terdiri dari sekertaris geujik dan aparatur desa gampong jalan, tokoh pemuda, tokoh masyarakat termotivasi untuk mendirikan unit usaha mengolah limbah ikan tuna menjadi kerupuk ikan tuna berbagai rasa, memasarkan produk, dan memahami bagaimana cara mengelola manajemen usaha setelah di berikan materi di karenakan desa gampong jalan memiliki potensi melimpah untuk di olah untuk mendukung potensi wisata yang ada di kecamatan idie rayeuk kabupaten aceh timur.

Melalui diskusi yang di laksanakan setelah pelatihan berlangsung menjadikan peserta paham akan hal-hal apa yang harus di perhatikan dalam pembuatan produk kerupuk ikan tuna, manajemen pemasarannya, manajemen usaha sehingga dapat meningkatkan pengetahuan mereka.

\subsection{Pembahasan}

Tim Pengabdian telah menyebarkan pemberitahuan dan undangan mengenai kegiatan seperti yang tersebut di atas ke beberapa anggota ibu-ibu rumah tangga setiap dusun desa gampong jalan, tokoh pemuda dan tokoh masyarakat.
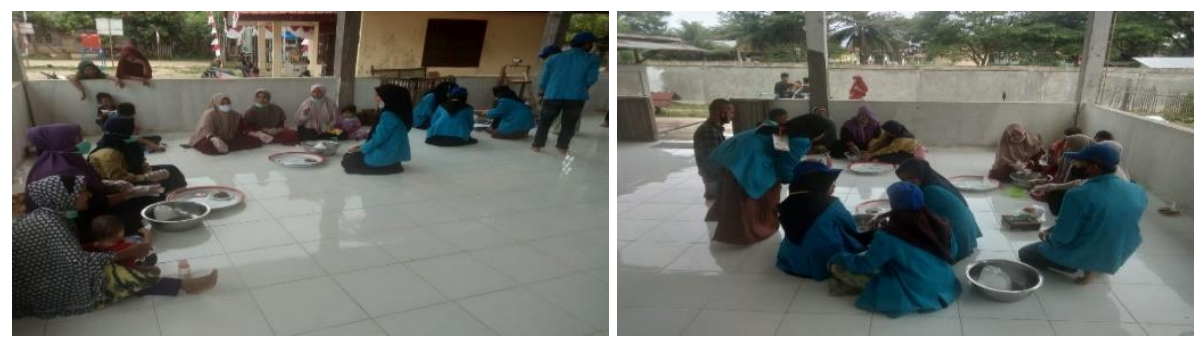

Gambar 2. Foto pelatihan pembuatan kerupuk ikan
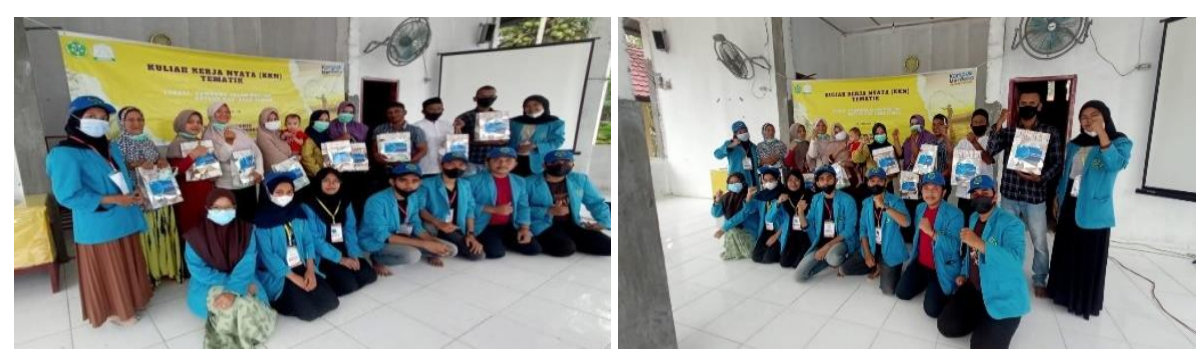

Gambar 3. Foto Bersama Ibu Rumah Tangga (URT) setelah selesai pelatihan

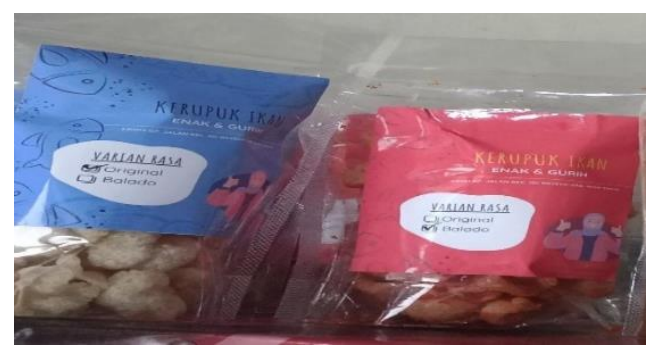

Gambar 4. Foto kemasan hasil produk

Adapun jumlah peserta pelatihan yang di undang sebanyak 35 orang, akan tetapi yang memenuhi undangan Tim hanya 30 orang. Hal ini di mungkinkan karena adanya kegiatan lain 
dalam waktu yang bersamaan. Kegiatan pelatihan di laksanakan pada tanggan 22 Agustus 2021 dengan mengambil tempat di musolah desa gampong jalan kecamatan Idi Rayeuk. Pemilihan tempat ini bertujun untuk memberikan kemudahan bagi para peserta untuk hadir dalam kegiatan ini. Secara umum semua peserta mengikuti kegiatan dengan baik . hal ini terlihat dari besarnya rasa ingin tahu warga tentang materi yang di berikan. Kegiatan tindak lanjut dimaksudkan untuk mengetahui dampak dari di adakan kegiatan ini.

Kegiatan tersebut berupa adanya kewajiban bagi para peserta untuk mempraktekan kembali pembuatan kerupuk ikan tuna supaya peserta bisa dan benar- benar paham disetiap proses pengolahan masing-masing produk tersebut. Hal ini bertujuan untuk mengetahui sejauh mana peserta paham dan menguasai teknik pengolahan, inovasi kemasan, cara pemasaran, dan manajemen usaha sehingga setelah kegiatan berlangsung mereka dapat mengaplikasikannya sendiri dan memproduksinya untuk dapat di jual dan menghasilkan laba artinya akan menambah pendapatan masyarakat/peserta pelatihan.

Pada sesi akhir kegiatan pelatihan dilakukan wawancara dan Tanya jawab kepada peserta mengenai tanggapan terhadap diadakan pelatihan yang dilaksanakan. Berdasarkan hasil wawancara dan Tanya jawab yang telah dilakukan oleh tim pengabdian, pada umumnya mereka tertarik dan antusias dengan kegiatan yang telah dilakukan serta mengusulkan agar diadakan kegiatan sejenis pada masa yang akan dating, tetapi materinya berbeda lebih di pertajam lagi materi kea rah manajemen pemasaran produk dan peningkatan kualitas mutu produk yang di hasilkan. Berdasarkan hasil evaluasi yang di lakukan dapat di ketahui bahwa sebagian besar peserta merasakan dampak positif dari kegian Tim pengabdi, pengetahuan peserta untuk mengolah ikan tuna meningkat dan membuka pikiran peserta untuk memanfaatkan peluang yang ada untuk meningkatkan pendapatan. sekitar $90 \%$ peserta secara aktif menanggapi positif keterampilan dan pengetahuan yang di sampaikan tim pengabdi masyarakat.

\section{KESIMPULAN}

Peserta menjadi paham dan mengetahui cara pembuatan Kerupuk Ikan Tuna berbagai rasa, cara pemasaran, manajemen usaha sesuai dengan materi yang di berikan, Wawasan mengenai kewirausahaan meningkat dan memotivasi peserta untuk dapat memanfaatkan peluang usaha pengolahan Kerupuk tulang ikan tuna sehingga meningkatkan pendapatan untuk membantu perekonomian keluarganya.

Hasil kegiatan ini di harapkan dapat memberikan manfaat bagi ibu-ibu rumah tangga desa gampong jalan, Perlunya pengembangan jejaring kerja sama untuk pemasaran, diversifikasi produk, Perlunya konsistensi komitmen mitra agar kegiatan tersebut bisa berjalan dengan efisien dan efektif sehingga kegiatan usaha semakin berkembang, Perlu adanya pendampingan kontinyu oleh pihak-pihak terkait baik pemerintah daerah/swasta dan istitusi pendidikan sampai kegiatan usaha pengolahan kerupuk tulang ikan tuna berjalan secara mandiri.

\section{UCAPAN TERIMA KASIH}

Terimakasih disampaikan kepada Sekolah Tinggi Universitas Samudra atas Kesempatan yang diberikan melalui program Kuliah Kerja Nyata tahun 2021, sehingga kegiatan ini dapat terlaksana dengan baik dan lancar, ucapan serupa juga disampaikan kepada Aparatur desa gampong jalan, tokoh masyarakat, tokoh pemuda, tokoh agama atas dukungannya dalam kegiatan ini sekali lagi saya ucapkan terimakasih.

\section{DAFTAR PUSTAKA}

Agusta, F. K., Ayu, D. F., \& . R. (2020). Nilai Gizi Dan Karakteristik Organoleptik Nugget Ikan Gabus Dengan Penambahan Kacang Merah. Jurnal Teknologi Pangan, 14(1), 69. https://doi.org/10.33005/jtp.v14i1.2184 
Deni, S., Hardjito, L., \& Salamah, E. (2007). Pemanfaatan Daging Ikan Tuna Sebagai. jurnal ilmiah agribisnis dan perikanan (agrikan UMMU-Ternate), 6(edisi 2), 14.

Hafiludin. (2011). Karakteristik Proksimat dan Kandungan Senyawa Kimia Daging Putih dan Daging Merah Ikan Tongkol (Euthynus affinis). J. Kelautan, 4(1), 1-10.

Huda, N., Pratiwi, A., Zulianti, R., Tinggi, S., Ekonomi, I., \& Masyarakat, I. B. (2021). PELATIHAN PEMBUATAN KERUPUK TULANG IKAN TUNA Asakota Kota Bima Provinsi Nusa Tenggara Barat Indonesia . Kelurahan ini memiliki wilayah pesisir pantai Sebelah Timur Desa Nipa, Sebelah Barat Desa Rite, Sebelah sebagian besar bekerja sebagai nelayan tradis. 2(2), 152.

Kusuma, T. D., Suseno, T. I. P., \& Surjoseputro, S. (2013). Pengaruh Proporsi Tapioka Dan Terigu Terhadap Sifat Fisikokimia Dan Organoleptik Kerupuk Berseledri. Jurnal Teknologi Pangan dan Gizi, 12(1), 17-28.

Pade, S. W., Murtaqi, A., Mutsyahidan, A., Irawan, F., Program, D., Teknologi, S., Pertanian, H., \& Gorontalo, P. (2021). Pemanfaatan limbah kulit ikan tuna menjadi kerupuk. 4(1), 1.

Pratiwi, T., Affandi, D. R., \& Manuhara, G. J. (2016). APLIKASI TEPUNG GEMBILI (Dioscorea esculenta) SEBAGAI SUBSTITUSI TEPUNG TERIGU PADA FILLER NUGGET IKAN TONGKOL (Euthynnus affinis). Jurnal Teknologi Hasil Pertanian, 9(1), 35. https://doi.org/10.20961/jthp.v9i2.12852

Purnamayati, L., Dewi, E. N., Sumardianto, S., Rianingsih, L., \& Anggo, A. D. (2019). Kualitas Kerupuk Kulit Ikan Nila Selama Penyimpanan. Jurnal Ilmu Pangan dan Hasil Pertanian, 2(2), 162-172. https://doi.org/10.26877/jiphp.v2i2.3216

Setyowati, N., Rahayu, W., \& Khomah, I. (2018). Pemberdayaan Usaha Olahan Tuna Melalui Pemanfaatan Limbah Ikan Tuna. Jurnal DIANMAS, 7(April), 70.

The National Standardization Body of Indonesia. (2009). SNI 2713.1:2009 Fish Cracker. BSN 2009, 1-5. 


\section{Halaman Ini Dikosongkan}

